\title{
Privileges for printed music in the Holy Roman Empire during the sixteenth century
}

\author{
Grantley McDonald and Stephen Rose
}

The words Cum privilegio on a printed book distinguish it as something special, an implicit promise of quality. Why is this book so privileged? What indeed is a privilege in the context of books? This chapter explores medieval antecedents for the privilege system and explains the typical structure of a supplication and the resulting privilege. It then examines musical editions from the sixteenth century which were protected by privileges, offering hypothetical remarks about the presence or absence of privileges in individual books. Consequently the chapter aims to show the ways in which authors, printers and publishers calculated the costs of privileges, and negotiated them with imperial and princely authorities.

This chapter focusses on privileges issued by the Holy Roman Emperor, the principal authority to grant such legal documents in German-speaking lands, and by subordinate authorities such as the Electors of Saxony and Brandenburg, who regularly issued privileges by the late sixteenth century. Evidence concerning privileges comes principally from information within the books, especially the title pages. Imperial privileges are also documented by material in the former Habsburg court archive in Vienna (Haus-, Hof- und Staatsarchiv [henceforth HHStA]), specifically from the archive of the imperial council (Reichshofrat), in the series Impressoria, which runs from the time of Maximilian to that of Napoleon. ${ }^{1}$ This collection is evidently incomplete; many books bearing the cum privilegio label on their title page are not documented in these files. Nevertheless, it still contains information concerning the publication of thousands of books. Further archival holdings relating to privileges within constituent territories of the Holy Roman Empire can be located in state archives such as the Sächsisches Hauptstaatsarchiv, Dresden.

\section{Antecedents of printing privileges}

Historians of copyright have often claimed that printing privileges were a kind of protocopyright. Moreover, they argue that the development of the printing press caused - or at least coincided with - a rising consciousness of the value of individual creative products, and hence to the idea of natural rights, basic to the notion of copyright. ${ }^{2}$ An extreme statement of this view is given by the legal historian Hansjörg Pohlmann, whose 1962 monograph goes so far as to compare the Cum gratia et privilegio rubric on a title page with the (c) sign. ${ }^{3}$ However, we would question this teleological view. ${ }^{4}$ On the one hand, it is clear that at least some medieval authors were intensely aware of the value and integrity of their works: witness the care with which poets such as Chaucer or Machaut, or prose writers such as Christine de Pisan or Jean Froissart, ensured the preservation of their work in reliable manuscripts. ${ }^{5}$ On the other hand, the legal mechanisms that allowed 
privileges to be given for printed books were already centuries old by Gutenberg's time. From the thirteenth century, the Latin word privilegium - usually translated into German as Privileg or Freiheit - indicated a special right granted by a higher authority to its subjects, whether individuals or corporations. It might consist in a monopoly for the production of, or trade in a particular good, perhaps one derived from a particular source. It might grant an exclusive right to exercise a particular skill or manufacturing process. It might confer an exemption from the regular course of law or custom. For example, the statutes of the Order of the Teutonic Knights (1264) note that those in holy orders were exempt from secular jurisdiction through 'privileges and freedoms issued by the See of Rome' ${ }^{6}$ The usage of various synonyms, such as Gnade and Herrlichkeit, implied the exceptional nature of the privilege and the existence of a feudal relationship between the parties involved. For example, a 1304 charter from Friedberg mentions a Gnade ('grace') granted by King Albrecht. ${ }^{7}$ The synonym Herrlichkeit - a 'lordly action', attested from the late fourteenth century onward in this narrow sense as an act done by a lord for a vassal - likewise presupposes the existence of a feudal relationship. ${ }^{8}$ From the middle of the fourteenth century onwards, the word privilegium also implied the existence of a document recording and delimiting its terms. ${ }^{9}$ The terms Privilegigewölblein and Privilegikämmerlein, as descriptors of the special archives where such documents were stored, are testified from 1613 and 1622 respectively. ${ }^{10}$ In the period of our examination, a privilege was thus a legal instrument through which an authority granted its recipient an extraordinary right. Such a suspension of normal laws and customs in a particular case required recording in a document that was then stored in a special archive with similar documents.

By contrast, copyright law holds that a creative product is automatically protected from infringement, either because of the public interest or the natural rights of the author. Copyright law protects a creator from the potential loss in rightful financial exploitation that such infringements might cause. No such sense of natural rights existed in common law before the seventeenth century; instead, the usual presumption was that any intellectual products were gifts of God to be shared for the common good. ${ }^{11}$ Previous attempts to interpret printing privileges as primitive expressions of copyright have failed to recognise that these legal instruments were specific exceptions to the general assumption of freely shared intellectual products. Privileges were not free and automatic rights, but were the result of a commercial calculation and the active solicitation of, negotiation of and payment for an extraordinary prerogative.

If we must seek a modern analogy to the early printing privilege, it is not copyright law, but patent law. ${ }^{12}$ The relationship with patent law is suggested by some of the earliest privileges for printing, which offered monopolies to practitioners in order to protect and encourage their technical innovations. In 1469 Johannes of Speyer, the first printer in Venice, received a privilege from the Republic for a period of five years, granting him the sole right to operate a press in the city. The privilege described printing as 'an innovation, unique and particular to our age... [which] must be supported and nourished with all our goodwill and resources'; it was revoked when Johannes of Speyer died a few months later. ${ }^{13}$ Similarly in 1498 Petrucci successfully petitioned the Republic for a twenty-year privilege to print polyphonic music for voices, organ and lute, using the double-impression technique of which he described himself as the 'first inventor' ('primo inventor'). As he said in his supplication, 'it is most widely reputed that your Serenities, through your grants and privileges, invite and inspire ingenious minds to think upon new inventions for the public benefit ${ }^{\prime 14}$ Such patents stemmed from a desire to protect technical innovation, especially in 
trades not already controlled by guilds, and also to encourage economic expansion, especially of specialist trades conducted by immigrants to specific towns and cities.

A further pre-modern context for privileges can be found in processes whereby publications were regulated and censored. The notion of the publication of a text ('librum in lucem edere') was not an innovation of the fifteenth century, but had existed since antiquity. In ancient Rome, the public reading of a text, often by the author, constituted its publication. ${ }^{15}$ In the middle ages, manuscript publication was normal. Harold Love has shown that scribal publication remained important into the seventeenth century. ${ }^{16}$ Yet the sheer number of copies that could be produced in a relatively short time by a printing press led to efforts by rulers and other authorities to control printed publication.

Attempts to regulate printing began early. In Leuven, printers joined the booksellers, who had become part of the congregatio universitatis in 1429, by swearing not to engage in fraudulent practices. This gave them the same legal immunities and exemptions as the other members of the university, but also placed them directly under the scrutiny of the faculty of theology. ${ }^{17}$ The medieval church had exercised censorship, but it was not formalised and regular. However, in 1515, Leo X promulgated the bull Inter sollicitudines, in which he prohibited certain classes of books and granted curial officials the right to censor works before they could be printed. In the Low Countries, this responsibility was exercised by the University of Leuven, under whose direct patronage printers in that city now stood. These developments led to the development of the various iterations of the Index of forbidden books, issued in manuscript from the 1520s onwards, and in printed lists from the 1540s. The 1521 Edict of Worms prohibited the printing, trade and possession of Lutheran and other evangelical works, under threat of fines, confiscation and even execution. ${ }^{18}$ From this point onwards, the process of applying for a privilege, especially in the areas of theology, law, politics and schoolbooks, involved an element of censorship.

A final context for privileges can be found in the various forms of official licence found in printed books. In the pre-Reformation period, many bishops commissioned printers to produce liturgical books for their dioceses. Some of these, such as missals and agendas, routinely contained printed music. Many contained a mandate or letter of commission from the bishop, usually printed at the beginning of the book, and sometimes with a woodcut bearing the bishop's heraldic arms. These mandates often commanded clergy within the bishop's jurisdiction to purchase copies of this edition. Many mandates justified the production of a given edition by claiming that there were not sufficient copies available, or that previous printed editions were in some way defective. Johannes Thurzó, coadjutor bishop of Breslau, reassured the priests of his diocese that the printers had gone to great pains to ensure the accuracy of the edition. ${ }^{19}$ In such cases, the bishop, who paid for the printing and saw to the disposal of the copies, thus acted as publisher. ${ }^{20}$ Such mandates are closely related to the medieval idea of the privilegium as an exclusive right to produce a good using a particular process. However, they necessarily lack other elements normally associated with printing privileges, notably the active solicitation of such a right from an authority.

\section{Applications for imperial privileges}

The first step in receiving an imperial privilege for printing or publishing a book was to submit a supplication to the emperor, by way of the imperial council (Reichshofrat). ${ }^{21} \mathrm{Al}-$ though some supplications were doubtless written by lawyers on behalf of their clients, 
they sometimes contain revealing personal information about the applicant or the circumstances surrounding the writing of the book. Submission of the supplication was subject to a fee, on a sliding scale according to variables such as the size and price of the book, and the length of the protection being sought, but usually stood between about five and twelve florins. ${ }^{22}$ This fee, however, was sometimes waived for applicants favoured by the emperor or his advisors. In addition to the petition, applicants might submit supplementary material such as manuscript or printed samples of the proposed work, or supporting letters from a patron or ecclesiastical authority. ${ }^{23}$

Decisions about the suitability of work were initially handled by the emperor himself, then deputed to trusted men such as the imperial counsellor Conrad Peutinger, the court historian Johannes Stabius or the jurist Wolfgang Ösler. ${ }^{24}$ As the process became rationalised and depersonalised, responsibility passed to the chancellor and the two advisory councils (Ratskollegien). ${ }^{25}$ Many surviving privileges are signed by members of the chancery (especially the vice-chancellor). Sometimes advice was sought from other specialists associated with the Habsburg court, for instance an evaluation from the Hofkapellmeister Philippe de Monte in connection with the privilege application by the tenor singer in the imperial chapel, Franz Sales. ${ }^{26}$ From 1569, the implementation and enforcement of privileges, as well as the collection of sample copies, was entrusted to the newly established imperial book commission, which regulated the book fair at Frankfurt am Main. ${ }^{27}$

Many of the first imperial privileges were granted to poets, historians, jurists and publishers associated closely with the court of Maximilian. During this early period, the granting of a privilege was thus an act of favour, reflecting glory on the ruler and binding the recipients more closely to him. ${ }^{28}$ As the system of privileges developed into a mechanism for regulating the book trade, prospective applicants had to balance the commercial benefits and prestige of a privilege against its potential disadvantages. The process of applying for a privilege cost time and money, both in application fees and delays. It demanded high standards of production, thus driving costs up even further. Furthermore, it invited close scrutiny of the applicant's output, perhaps placing him or her under unwelcome restraints. After all that, a privilege was no guarantee of commercial success. In his supplication for an unusually long privilege of twenty years, the mathematician Philipp Apianus claimed that the market for such books was very small: he was lucky if three or four copies of his book sold in a year. ${ }^{29}$ The same evidently went for many music books, explaining why they were still available for sale decades after their publication. ${ }^{30}$ The later sections of this chapter examine the privileges for specific music books in light of the balance struck by publishers and composers between commercial risk and princely protection.

\section{The format of privileges}

The individual files preserved in the Impressoria series of the archive of the court council often include only the drafts of privileges, since the fair copies were typically sent to the applicant. These drafts can be difficult to read, on account of numerous excisions and additions that often indicate how the terms of the privilege were hammered out in the council. Figure 9.1 shows the draft for the 1603 privilege to Philipp de Ohr for Hieronymus Praetorius' Latin motets, with corrections updating the document as the basis for a subsequent privilege granted to Georg Frobenius. In some cases, no text for the privilege survives, but annotations have been added to the supplication, indicating that the privilege had been granted and for how long. 


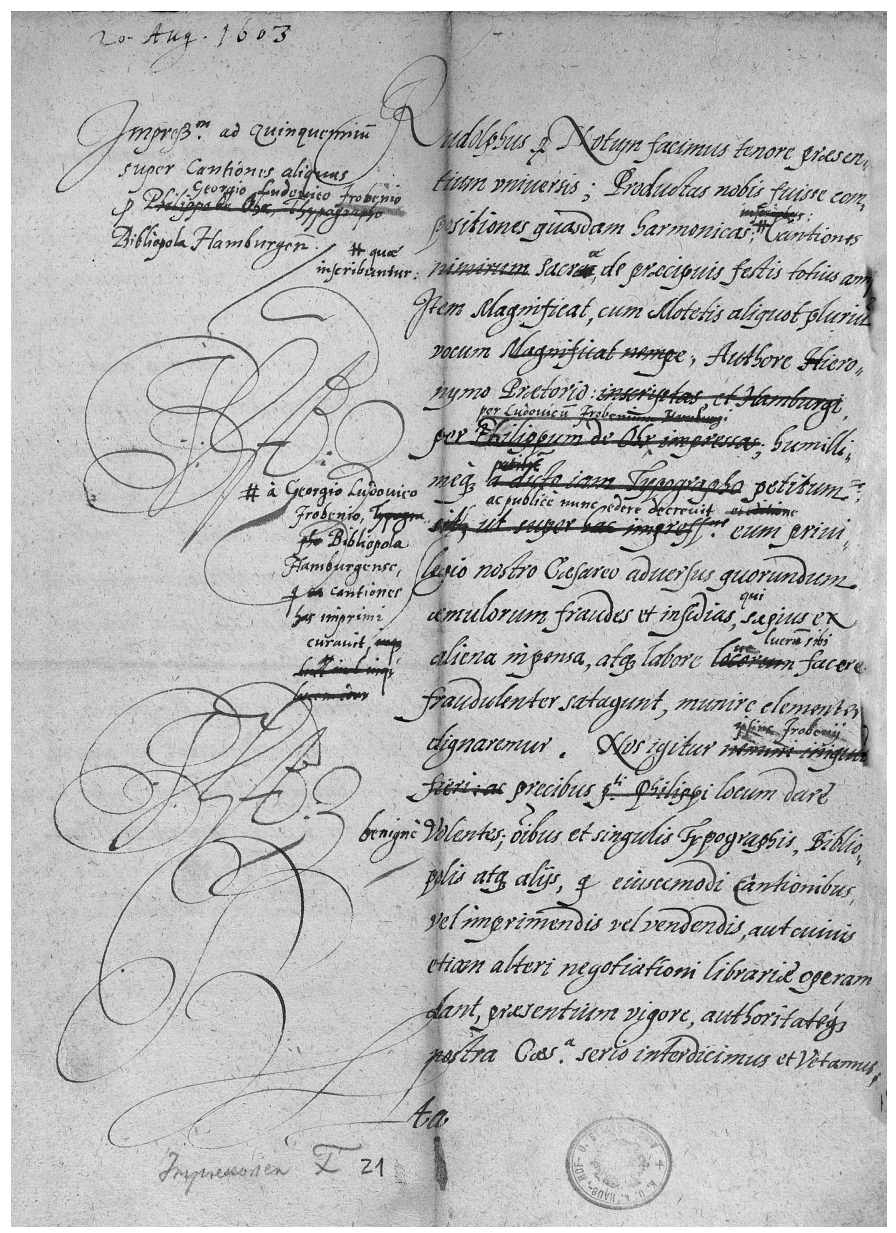

Figure 9.1 Draft of imperial privilege to Philipp de Ohr for Latin motets of Hieronymus Praetorius, 20 August 1603, amended for subsequent privilege to Georg Frobenius.

Source: Vienna, Haus-, Hof- und Staatsarchiv, RHR, Impressoria, 21-32, fol. 231 .

Three kinds of privilege could be offered.$^{31}$ Most common were special privileges, offering protection for a specific book. Less frequent were general privileges, protecting the entire output of a publisher or author within a particular genre for a defined period. Rarest of all were universal privileges, protecting the past, present and future works of an author in perpetuity. ${ }^{32}$ Orlande de Lassus is the only musician known to have received a universal imperial privilege, doubtless because of his fame. ${ }^{33}$

The formulations used in the privileges often employ stock phrases that originate in the medieval traditions of the chancery. Even if parts of the formulation are bolted together from legal boilerplate, the phrasing of each privilege is part of the enactment of imperial power in an individual case. Typically, a privilege includes several distinct parts. ${ }^{34}$ First is an enumeration of the name and the titles of the emperor. This serves both to project his imperial majesty and to guarantee his territorial and political jurisdiction over the matter. Next, the publicatio (also known as the promulgatio or notificatio) indicates that the contents of this privilege should be published. This part of the privilege was important, since it was 
legally and psychologically necessary to make one's claim to a privilege known in order to prevent contraventions. One printer-bookseller, Nicolaus Bassaeus, posted his privileges on the shutters of his shop..$^{35}$ From about 1569, the imperial book commission stipulated that booksellers should display their privileges at the Frankfurt book fair. ${ }^{36}$

The next section of the privilege, the arenga, outlines the reasons that moved the emperor to grant the privilege. Typically these included the promotion of the public good, and the protection of the investment of money, effort and labour undertaken by the applicant. It was important for the emperor that products associated with his name would not damage his reputation or the dignity of the church, but were of high quality and value. Accordingly, some privileges specify that books under privilege were to be printed on good paper with good type well set. ${ }^{37}$ The arenga tends to be most detailed in privileges from the reign of Emperor Maximilian I; under subsequent emperors, it was more common to include a brief narratio giving reasons taken from the applicant's supplication for the granting of the privilege.

Next follows the dispositio, which declares the will of the emperor or his vicar in protecting the publication. This section usually specifies the duration of the privilege, usually three, five or ten years. It also outlines the punishment for those found guilty of infringing a privilege. First, the remaining copies were usually seized; second, the guilty party was fined, usually ten Marks of pure gold, but sometimes as much as thirty Marks. (According to the Reichsmünzordnung of 1524, a Mark was equivalent to eight ounces; at 2021 prices, eighty ounces of gold would cost about $€ 118,000$ or US $\$ 142,500$, though an exact equivalence in buying power is difficult to calculate.) Half of this amount was to be paid to the fiscus (chancellor of the exchequer) of the imperial chancery, as a fine for contravening an imperial command; the other half was to be paid to the holder of the privilege as damages. The seized books were also handed over to the holder of the privilege. Some imperial privileges authorised their holders to take action themselves by confiscating pirated copies. ${ }^{38}$

Most privileges also lay out the responsibilities incumbent on the privilege holder; failure to conform to these requirements could lead to the revocation of a privilege. Foremost among these responsibilities was the submission of deposit copies. In 1538, a voluntary agreement encouraged printers and publishers to submit sample copies to the University of Vienna. ${ }^{39}$ From the middle of the sixteenth century, many privileges obliged privilege holders to submit deposit copies to the imperial council. For example, a privilege granted to Heinrich Petri specified that a failure to send 'a certain number of copies' ('aliquot exemplaria') immediately following publication would result in the loss of the privilege. ${ }^{40}$ By the seventeenth century, this requirement had become more specific and more onerous, typically demanding between three and seven copies, so that there were individual exemplars for the imperial chancery, the court library and the emperor himself. Even higher demands for deposit copies were made by subordinate princes who issued privileges, with the Elector of Saxony typically demanding between twelve and eighteen copies. ${ }^{41}$

A further set of responsibilities committed the holder of the privilege to submit to various types of censorship. In the 1540s and early 1550s, some imperial privileges granted to non-Catholics contain a clausula religionis, forbidding the publication of works contrary to the Catholic faith. From the late 1570s, in an atmosphere of heightened confessionalisation, numerous privileges stipulate that the books should not damage the Catholic faith nor the imperial constitution. An example can be found in the 1603 imperial privilege granted to the Hamburg publisher Philipp de Ohr for the music of Hieronymus Praetorius: presumably because Praetorius was a Protestant, this privilege instructed 'that the songs should contain nothing in the preface or in the texts that is scandalous or opposed to Roman 
Catholic orthodoxy, or to the imperial constitution'.${ }^{42}$ Such provisions were motivated by the desire to repress heresy, to avoid associating the emperor with ideas inconsistent with his position, and to prevent the publication of material likely to cause political unrest. ${ }^{43}$ However, it is unclear how far such provisions were upheld, particularly for general privileges that could cover an array of future publications. Further research is required to show how far the imperial book commission in its activities at the Frankfurt book fair investigated the religious content of music books issued under privilege.

Although the archives generally contain only draft versions of privileges, each of these documents would also be issued in a fair copy. Often fair copies of privileges were impressive documents on large oblong sheets of paper. They contained the signature of the granter and the imperial seal, as a guarantee of authenticity and as a further enactment of imperial majesty. The magnificence of such documents indicates that the power contained in privileges was partly generated by the ritualistic performance involved in granting these legal instruments: through such splendour, issuers of privileges hoped to persuade lesser authorities in the decentralised German realms to uphold their will. ${ }^{44}$

\section{Privileges for music books before 1550}

Of the nearly 1200 titles listed in $v d m$ (which covers the period up to 1550), only sixty explicitly mention privileges, granted mainly by the emperor, sometimes by territorial princes, both secular and ecclesiastical. Of these, fifty-six were printed between 1501 and 1550, the final year of the sample. In all likelihood, many of these items were covered not by specific privileges but rather by general privileges granted to such individuals as the printer Johann Petreius or the editor-publishers Sigmund Salminger and Hans Ott. It is no coincidence that these men were based in the most important commercial centres of German-speaking land before 1550, namely, Nuremberg and Augsburg.

The first known music book issued under an imperial privilege was Arnold Schlick's Spiegel der Orgelmacher (Mirror of the organ builders, 1511). The ten-year privilege granted to Schlick, printed in the Spiegel, is addressed to the officers of the empire as well as to all printers, publishers and booksellers, and emphasises the work's utility: Philip, Elector Palatine, had encouraged Schlick to write a work on the construction of organs suitable for accompanying the chant (that is, probably in alternation). Schlick undertook this work to reveal these skills to everybody, first to the honour of God, and second to save some of the expense that would otherwise be incurred in maintaining unsound instruments. Schlick had applied for a privilege for two reasons: first, so that he might more easily find a printer who would print this work with a 'sharp and legible font', and second, so that he might derive some financial profit from the sale of the book in recompense for his efforts. In seeking to protect his disclosure of specialised knowledge about organ-building, Schlick's privilege shows some affinities with those patents granted to protect technical innovation. The privilege was intended to cover both the Spiegel and another work, Tabulaturen etlicher Lobgesang und Lidlein uff die Orgeln und Lauten (Tablatures of certain songs of praise and secular songs for the organ and lute), which was in the planning stage. Maximilian granted the privilege for the reasons detailed in the supplication, and to promote the common good. For this reason, he exhorted the officers of the empire and all members of the book trade to protect Schlick, for Maximilian's sake. Accordingly, they were not to print the work within ten years without Schlick's permission, or to permit unauthorised editions printed in Italy or elsewhere outside the empire to be sold within its boundaries. Imperial agents were to prevent the unlawful reprinting of Schlick's work, to avoid the necessity of invoking legal remedies. ${ }^{45}$ 
A poem included in Schlick's Tabulaturen (1512) refers directly to this privilege:

Diß artlich bůch und künstlich wergk

Gepflantzet aus Orpheus bergk

Getruckt zu lob got vnd der welt

Nůn mergk was wirt hiebei gemelt

Das die keiserlich maiestat

Dis buch gefreit und bgnadet hat

Keynen trucker zů trůcken noch

In zehen iarn bei grossem roch

Und straff darzů einr grossen pen

Wie die in dem mandat dann sten

Das thů ich euch verkünden hie

Das keiner sich entschuldig wie

Ym das nit offenbaret wer

Der das verbrech dem würds zů schwer

('This elegant book and artful work, / cultivated from Orpheus' mountain, / [is] printed to the praise of God and [for] the world./ Mark now what is detailed here:/ that His Imperial Majesty / has given this book a privilege, / that no printer may reprint it/ for a period of ten years, under pain of great displeasure/ and moreover punishment of a large fine, / as detailed in the mandate./ I inform you of this now, / that no-one might excuse himself by claiming/ that this was not brought to his attention./ Those who offend will suffer considerable difficulty.') ${ }^{46}$

This text, building on the tradition of vernacular didactic poetry, emphasises the pious intention and utility of the book, and advertises the existence of an imperial privilege of ten years, under pain of a stiff penalty. The inclusion of this warning was considered sufficient notice to any potential pirates.

The next musical work to contain an imperial privilege is Johannes Foeniseca's Quadratum sapientiae (Augsburg: Johann Miller, 1515 [vdm 436]). It bears a privilege from Maximilian I that forbade unauthorised reprinting for five years, under pain of five gold Marks and confiscation of unrightfully printed copies. However, this book is a kind of encyclopaedia in which music comprises only one part. It thus stands closer to the genre of learned literature than printed music, even if it does contain a little musical notation, printed in multiple impression. The same may be said for two further works containing a little musical notation underlaid with text in one of the biblical languages: Johannes Reuchlin's De accentibus et orthographia linguae hebraicae (Hagenau: Thomas Anshelm, 1518) and Philipp Melanchthon's Institutiones graecae grammaticae (Hagenau: Thomas Anshelm, 1518). Another 'learned' work of music theory covered by imperial privilege was Ottmar Luscinius' Musurgia, first printed in 1536 with a five-year privilege and reissued in 1542 with under a further five-year privilege. These privileges were held not by Luscinius, but by the printer-publisher Schott. ${ }^{47}$

Most music printed in the Empire during the first half of the sixteenth century, if covered by a privilege at all, was protected by a general privilege held by the printer in his capacity as publisher. For example, the first collection of polyphonic music granted an imperial privilege - not to mention a papal privilege as well - was Liber selectarum cantionum (1520), which was presumably covered by a privilege held by the printerpublishers Sigmund Grimm and Marx Wyrsung, though in the absence of further 
information within the edition, it is difficult to be sure. ${ }^{48}$ Sometimes printers, acting simultaneously in the capacity of publishers, received a privilege for a particular work. For example, Peter Schöffer the Younger received a privilege specifically for a collection of twenty-eight motets for five voices (1539). Ferdinand's grant mentioned that Schöffer had specifically sourced pieces in Italy, thus signalling both the cost he had incurred in collecting this music for the German market, and the cultural premium of these pieces, composed with 'gravity and sweetness'. ${ }^{49}$ Yet general privileges were undoubtedly more common. Of the fifty-six titles with privileges in the $v d m$ database from 1501 to 1550, ten were printed and published by Johannes Petreius. The Impressoria files contain only one supplication from Petreius, dated 1538, for a five-year privilege covering publications of psalms, probably the Tomus primus psalmorum selectorum (1538), Tomus secundus psalmorum selectorum (1539) and Tomus tertius psalmorum selectorum (1542). ${ }^{50}$ None of the other privileged editions by Petreius indicates who held the privilege, but it is likely that Petreius simply held a general privilege, which has however left no documentary trail in the Impressoria files.

Nine of the titles in the $v d m$ database with privileges were printed by the musically illiterate, commercially unscrupulous but visually talented printer Hieronymus Formschneider, but he was not their publisher. Indeed, there is no evidence that Formschneider held any privileges. ${ }^{51}$ Rather, most of his music books were protected by privileges granted either to the editor and publisher Hans Ott, or to the lute teacher Hans Gerle, to whom we shall return. In 1533 and 1545, Ott applied for privileges to protect his financial investment. The original Latin text of his first, four-year privilege was printed in the Novum et insigne opus musicum (1537), but had appeared earlier in German translation in Hundert und ainundzweintzig newe Lieder (1534). ${ }^{52}$ Ferdinand's privilege to Ott praises his zeal and diligence, and the qualities of the music he had collected. These pieces are characterised as serious and delightful, thus conforming to the poetic requirement of instruction and delight (Horace, Ars poetica 333). Ferdinand justified the privilege as a means to protect Ott from financial loss and thus indirectly to promote the moral formation of the young through music. The privilege also acknowledges the multiplicity of printing techniques available in the sixteenth century by explicitly covering all music published by Ott, however it was printed (excusa quoquo modo). The protection was also retroactive, covering Ott's back-catalogue as well as future publications, for the duration of the privilege's validity. It proscribed not only the unauthorised reprinting and sale of Ott's books, but also any attempt to reprint or sell them. Accordingly, it was aimed not merely at other printers, but also more broadly to all authorities and especially to book copyists and dealers (bibliographi $\mathcal{E}$ bibliopoli), who were forbidden from dealing in illegally reprinted copies. ${ }^{53}$ Those found guilty of infringing Ott's privilege were to be fined ten gold Marks, of which half was to be paid to the imperial treasury, and half to Ott. The contraband copies were to be seized and ceded to Ott.

Although Ott's privilege explicitly addresses music scribes, they were not forbidden from exercising their primary activity - that is, copying books, including music books, by hand - but simply from trading illegally printed copies. This was perhaps for practical reasons. It was probably impractical to police the trade in manuscript music, and difficult to prove that a scribe had copied from a source protected by privilege. It is also possible that a policy decision lay behind this exclusion: most manuscript copies were presumably made by and for students, in whose interest Ott's privilege was granted in the first place. Moreover, the production of manuscript in low numbers may have been deemed insufficiently threatening to warrant proscription. 
Ott was not the only active editor-publisher of polyphony in mid-sixteenth-century Germany. Ten of the fifty-six titles with privileges from 1501 to 1550 in the vdm database were edited by Sigmund Salminger. ${ }^{54}$ Of these, four were printed by Melchior Kriegstein, and six by Philipp Ulhart the Elder. These titles were covered by Salminger's privilege, granted to him on 4 October 1539 in his capacity as editor and publisher. ${ }^{55}$ Commercial considerations played a major part in the explicit justification of these privileges granted to specialist editor-publishers such as Ott and Salminger, because the imperial authorities sought to protect those financially dependent on their ability to make a living from commercial sales of sheet music. The decentralised nature of the music printing market in German-speaking lands also meant that granting a privilege would not easily lead to a monopolistic situation, in the same way as it did in France, where the printing of music lay in fewer hands. ${ }^{56}$

Maximilian's successors Charles V and Ferdinand I granted privileges to individual instrumentalists who wished to protect their instructional manuals and collections of repertory from piracy. Prior to the introduction of printed tablatures, such instrumentalists would have normally kept their repertory secret, disclosing it only to pupils or apprentices who paid the necessary fee; they therefore risked losing a major source of their income if they disclosed their repertory in print. ${ }^{57}$ Hans Gerle, who commissioned Hieronymus Formschneider to print his books, applied for an imperial privilege after publishing his first book of lute tablatures (1532), but before publishing his second (1533). ${ }^{58}$ It is not known whether Gerle had experienced the annoyance and loss caused by unauthorised reprints of his work, or simply wished to guard against this possibility; in either case, no pirated copies of his books have survived.

The lutenist Hans Neusidler likewise aggressively protected his exclusive right to publish his books of tablatures, which were printed by several printers at Nuremberg on commission from Neusidler, who acted simultaneously as author and publisher. Neusidler advertised the existence of this privilege by having it printed prominently at the head of his volumes. The privilege claims that Neusidler had been prompted to apply for it after realising that a collection of 'certain pieces for the lute and similar instruments' ('ettliche stückh zu der Lauten vnd der gleichen Seytelspil gehörig') published 'for the good of the young and lovers of this art' ('der Jugent vnnd allen Liebhabern derselben kunst/ zu gutem') might be immediately pirated by others 'for their own use and advantage' ('zu jrem selbs nutz vnd vorteyl'). This is not to say that such a loss had actually occurred; all the verbs are in the subjunctive, which implies that Neusidler was guarding against potential loss rather than reacting to real loss. It is also unclear whether the collection mentioned in the privilege is a lost and otherwise unknown work predating Neusidler's Newgeordnet künstlich Lautenbuch (1536), or this book itself. In any case, Neusidler successfully applied for a privilege, which was granted on 15 May 1535 for five years. ${ }^{59}$ Both parts of Neusidler's instruction manual appeared in 1536 under this privilege (vdm 33, 34). When he published a new collection in 1540, it was protected by a two-year privilege. ${ }^{60}$ On 22 February 1543 , he received a five-year extension of his original privilege, under which he published four known editions (vdm 1030, 1031, 1032, 1118). His last known collection appeared in 1549 under a further five-year extension (vdm 1136). The correspondence of the Zwickau town clerk Stephan Roth clarifies the financial risk that Neusidler took in the publishing and sale of his lute-books: reportedly the composer bought all the copies of the print-run of the Lautenbuch from Johann Petreius at one florin each, to sell on at two florins each. ${ }^{61}$ By acting as a self-publisher, Neusidler sought to retain the income that previously he would have gained by teaching the lute and selling repertory to pupils. As with Gerle, Neusidler's 
privileges show that the imperial authorities recognised the need to protect instrumentalists who shared their technical skill in print in order to promote the public good.

The materials in the Impressoria files in the court archive in Vienna illuminate the ways in which the terms of the privilege were worked out, and their provisions realised. In 1544, Matthias Apiarius, former business partner of the late Peter Schöffer the Younger, applied for a privilege to protect some of his works, including musical editions, from piracy (see Appendix 9.1). His petition has not survived, but we have the draft of the privilege, granted by Ferdinand on 20 May 1544. This privilege emphasises that Apiarius printed these works 'for all lovers of art and for future remembrance'. The draft originally listed 'certain copies, compositions and books, namely two versions of the Magnificats in all the tones, responsories, hymns and motets, as well as books about music, arithmetic, the Catalogue of years and princes [i.e., the Catalogus annorum et principum, 1540]'. This was then altered to 'new sacred and secular songs, compositions and motets, as well as other works about music and arithmetic'. The authors listed were Johannes Vannius (Wannenmacher), Cosmas Alder and Sixt Dietrich. The privilege then states that Apiarius wished to protect himself from the loss of effort that would result from the open or covert transport and sale of unauthorised reprints. For this reason, Ferdinand informed the population of his territories, especially printers and book dealers, that contravention of the privilege bestowed on Apiarius would result in a fine of ten Marks, of which five would be paid to the imperial chancery, and five to Apiarius.

The privilege seems to be retroactive as well as prospective, for it refers to editions that had already appeared as well as ones that were yet to appear. The 'two versions of the Magnificats in all the tones' ('zwayerlay Magnificat ad omnes Tonos') may refer to the two editions of Sixt Dietrich's Magnificats in the eight tones, liber primus, which Apiarius printed in 1535 and again in 1537, or perhaps to lost reprints of this collection. Alternatively, it may refer to a liber secundus which has since disappeared. Only one complete set and one bassus partbook survive from the 1537 edition of the liber primus, which suggests that survival rates for such editions are very low. The only known work by Johannes Wannenmacher printed by Apiarius appeared in 1553. In the dedication of that work, dated 13 August 1553, Apiarius announced his intention to publish further, larger-scale works by Wannenmacher, Alder and Dietrich. ${ }^{62}$ In partial fulfilment of this promise, he published a volume of hymns by Alder in 1553, but no more editions of music by Sixt Dietrich or Wannenmacher from Apiarius' presses are known. ${ }^{63}$ It is possible that such editions have vanished without a trace. Alternatively, it is possible that Apiarius' application for a privilege in 1544 reflected a long-term business plan that was realised only partially. This would hardly be surprising. As John Kmetz, Elisabeth Giselbrecht and others have repeatedly shown, music represented an insignificant segment of the output of every sixteenth-century German printer who bothered to enter this market. ${ }^{64}$ In the ten years between 1544 and 1553, VD16 identifies seventy-seven editions printed by Apiarius; further editions have almost certainly disappeared without trace. Thus Apiarius' failure to print any further editions of Wannenmacher's music was hardly likely to push him over the edge of bankruptcy.

The material in the Impressoria files also gives information about editions which were evidently planned, but which have left no other evidence of their existence. For example, in 1544, the Nuremberg printer Hans Kilian presented a supplication to the emperor, in which he describes how he, mindful of the social benefits of music, especially for the young, had asked some experienced musicians to edit instrumental tablatures which he intended to publish to the honour of the emperor and for the benefit of beginning students (see Appendix 9.2). However, conscious of the risk of financial loss, Kilian requested a privilege 
to protect him against potential piracy of any musical work he might publish over the next ten years, whether tablature, vocal music or any other kind of music book. Moreover, he requested that this protection should extend for ten years from the publication of each title. The imperial council approved Kilian's request, at least for tablatures; however, no printed tablatures printed by Kilian are known. Once again, this could be because no copies have survived, or because he never acted on this privilege. Similar examples of privileges for works that never appeared or are now lost can be found in the later sixteenth century and early seventeenth century. ${ }^{65}$

The $v d m$ database also contains some surprising cases relating to privileges. In 1525 , the Strasbourg printer-publisher Wolfgang Köpfel printed the first evangelical church orders for Strasbourg, including the songs to be sung in the liturgy there. From 1526, he reprinted this order at least four times, with strongly worded warnings directed towards other printers and booksellers in which he asserted that he possessed a privilege that prevented others from producing unauthorised reprints of these books, under pain of fines. ${ }^{66}$ Unfortunately none of his editions includes the wording of this privilege. The earliest known editions by Köpfel that include references to this privilege are a manual on commercial arithmetic and a Hebrew grammar, both published in 1525 under a three-year imperial privilege ${ }^{67}$ Technically, publication of the evangelical liturgies would have been banned under the terms of the Edict of Worms (1521), which prohibited the publication of 'heretical' writings. The Hebrew grammar was accompanied by a letter of commendation from Ulrich Varnbühler, chancellor of the imperial regency council, addressed to the author of the book, Wolfgang Fabritius Capito, a relative of the printer Köpfel. It is possible that Köpfel had received a general privilege for the Hebrew grammar, perhaps through Varnbühler's support, and simply slipped his evangelical church orders under this blanket protection. Köpfel's 1530 edition of the Strasbourg liturgy and hymn book also contains a reference to an imperial privilege; either he had renewed the three-year privilege first mentioned in his titles in 1525 , or simply hoped that no-one would notice that his privilege had run out. ${ }^{6}$

Since the Impressoria series in Vienna contains no privilege supplication from Wolfgang Köpfel, we can only speculate about the nature of his privileges. However, in 1559 Wolfgang's son and heir Paul Köpfel applied for an extension of the privilege granted to his father, justifying it on the grounds of financial difficulty: Wolfgang had suffered financial disaster as a result of a shipwreck on the Rhine, which his heirs were still paying off. Although Paul Köpfel applied for a privilege of ten years, he received protection for only three (see Appendix 9.3).

\section{Privileges for music books 1550-1600}

An account of printing privileges for music books after 1550 is hindered by the lack of any music-bibliographical tool with coverage or depth equivalent to $v d m$. The following comments are based on inspection of surviving copies (often guided by library catalogues with full transcriptions of title pages) and further archival work in Vienna and Dresden. Without comprehensive bibliographical coverage, it is not possible to give statistics for the frequency of privileges. Nonetheless, some trends are evident, including the growing importance of privileges from Protestant rulers (notably the Elector of Saxony) and the increasing use of privileges for single-composer partbook collections of vocal polyphony.

Already in the first half of the sixteenth century, imperial privileges were primarily associated with publications promoting Catholic orthodoxy, whereas publishers of more aggressively Protestant works would sometimes seek privileges from Protestant princes such as Joachim II of Brandenburg. ${ }^{69}$ In the second half of the sixteenth century, wider 
confessional divisions opened in the book trade, with the increasing activities of the imperial book commission as censors at the Frankfurt am Main book fair leading to the expansion of the Leipzig book fair for Protestant publications. The Leipzig book fair was regulated by the Saxon book commission, which upheld Saxon privileges against unauthorised publications. Consequently, publishers of Protestant literature, or publishers focussing on a market serving Saxony and adjacent territories, increasingly sought privileges from the Elector of Saxony. From the 1570s onwards, Electoral Saxon privileges are occasionally found on music published in cities such as Dresden, Leipzig and Magdeburg. Some of the first known partbooks to bear a Saxon privilege are the various publications of music by Gallus Dressler issued in Magdeburg, including his Cantiones quatuor (1570, which states a five-year Saxon privilege on its title page) and XVI Geseng (1570). ${ }^{70}$ The unspecified privileges mentioned on the title pages of Leipzig hymnals of the 1580s were presumably also issued by the Elector of Saxony. ${ }^{71}$ The earliest archival documentation currently known for Saxon privileges for music, however, dates from 1594. It consists of a petition and draft privilege for Seth Calvisius' Hymni sacri latini et germanici and a petition and draft privilege for Abraham Ratz's edition of Jakob Regnart's songs. ${ }^{72}$ Electoral Brandenburg privileges were also used by musicians in that territory, for instance, Bartholomaeus Gesius, and would be a fruitful topic for further research. ${ }^{73}$

The second half of the sixteenth century saw a substantial growth in the number of music publications produced annually in German-speaking lands. Much of this growth consisted of editions containing vocal polyphony by a single composer, suggesting that increasing initiative was taken by some musicians to publish their music, and also that a composer's name held a growing power to sell music. ${ }^{74}$ The title pages of many of these partbook editions mention a (usually unspecified) privilege, giving the impression of increasing use of privileges in the period (although confirmation of this hypothesis would require a comprehensive statistical survey). In 1565 the Munich printer Adam Berg received from Maximilian II a general privilege covering all his output; this imperial privilege is stated on the title page of all of Berg's music publications, and an excerpt from it is printed in Berg's most prestigious outputs such as the Patrocinium musices, a series of choirbooks containing sacred polyphony by Orlande de Lassus (see Figure 9.2). ${ }^{75}$ Most of the partbook editions issued by the Gerlach firm in Nuremberg likewise list an imperial privilege on their title pages. ${ }^{76}$ Although no archival documentation has so far been located, it is likely that Katharina Gerlach and her partners held a general imperial privilege. Alternatively, it is possible that publishers submitted summary lists to the relevant authority for a privilege to be issued or renewed. Such a list survives from the Leipzig publisher Abraham Lamberg in conjunction with the renewal of Saxon privileges; it specifies Erhardt Bodenschatz's anthologies Florilegium selectissimarum cantionum (1603), Psalterium Davidis (1607) and Harmoniae angelicae cantionum ecclesiasticarum $(1608)^{77}$ alongside many educational, devotional and theological books. Through the protection of general privileges, publishers sought to protect their investment in titles that they presumably considered would sell well.

Musicians also applied for privileges for the publication of their own works. Some of these were instrumentalists, doubtless motivated by the same reasons discussed above, to protect themselves against the risk of publishing repertory that they would normally disclose only to pupils for a fee. Archival documentation exists for the imperial privileges issued to the lutenists Valentin Bakfark and Melchior Neusidler. ${ }^{78}$ The Leipzig organist Elias Nikolaus Ammerbach advertised a six-year imperial privilege on the title page of his 1575 organ tablature and this may likewise have been an individual privilege or could have been the same general privilege presumably held by Gerlach (his publisher). ${ }^{79}$ In the last quarter of the seventeenth century, supplications for privileges were also made by 


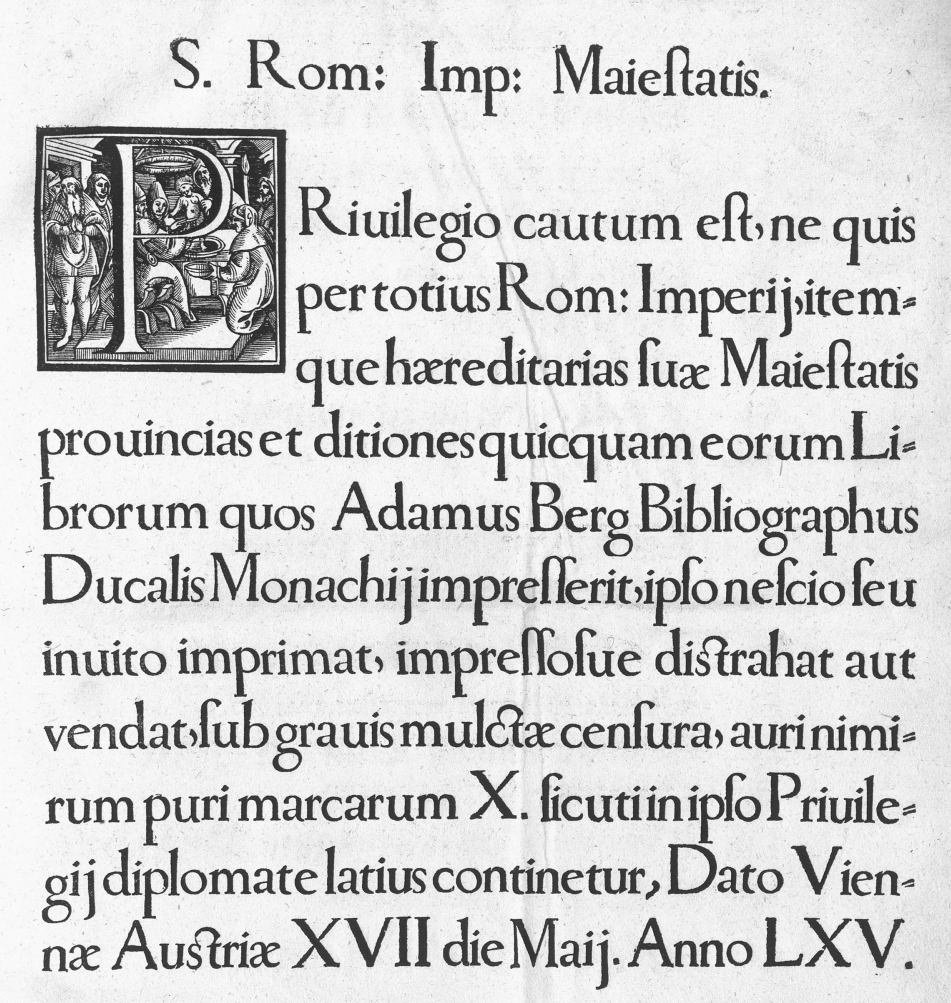

Maximilianus.

I.V.Zalij.

$$
\begin{aligned}
& \text { Ad mandatum Dñielecti } \\
& \text { lmperatorisproprium. }
\end{aligned}
$$

C.V.Lindegk.

Figure 9.2 General imperial privilege to Adam Berg as printed in Orlande de Lassus, Patrocinium musices (Munich: Adam Berg, 1573).

Source: Munich, Bayerische Staatsbibliothek, 2 Mus.pr. 11-1.

composers of vocal music. One of the first composers documented archivally to have such an individual privilege was Lassus, with his 1581 perpetual imperial privilege for past, present and future works. ${ }^{80}$ Lassus' example may have encouraged other musicians contemplating the publication of their polyphonic compositions to apply for imperial printing privileges. Examples documented archivally include Jakob Handl (Gallus), Hans Leo Hassler and Franz Sales. ${ }^{81}$ However, references on title pages of printed music suggest that a wider range of musicians may have applied for individual privileges, despite the lack of archival documentation. As already mentioned, the publications of the Magdeburg cantor Gallus Dressler list a Saxon privilege, and this privilege is also mentioned (along with an imperial one) on Dressler's music issued by Katharina Gerlach. ${ }^{82}$ It seems unlikely that Gerlach would seek a Saxon privilege given that her output was usually protected by imperial privileges and targeted for sale in markets under imperial jurisdiction; more likely 
is that this Saxon privilege was acquired individually by Dressler, which might explain why Gerlach's editions of his music carry the rubric 'Imprimebat cum consensu Autoris' ${ }^{83}$

The increasing use of individual privileges for musicians gave rise to the question of whether such privileges took precedence over a publisher's general privilege. In 1582 Katharina Gerlach published the Fasciculi aliquot sacrarum cantionum, containing many Lassus motets that had previously been published by Adam Berg. The title page of Gerlach's edition clarified it was published under the terms of Lassus' individual privilege ('Privilegio sacrae Caes. Maiestatis peculiari'), and an extract from this privilege was contained within..$^{84}$ Berg, however, petitioned the Nuremberg council, complaining that this edition contravened his own general privilege. The council dismissed his case on the grounds that 'she [Gerlach] printed the songs with the knowledge and consent of Orlandus, and the latter bears himself another and better special privilege' compared to Berg's. ${ }^{85}$ Berg appealed against the decision to the imperial Hofrat in Vienna, which upheld the initial ruling:

Because the privilege is general and does not relate specifically to these songs, and [as a privilege granted by] Maximilian II it has expired on his death, and because it is not known whether Berg has a special privilege for Nuremberg or not, and particularly because the author himself has sold his books, because the executio of the privilege states that he can take books for himself, therefore [Berg's] petition was denied. ${ }^{86}$

Analysing this verdict, Pohlmann commented that 'the notable feeling for a conceptual separation of publisher's rights from creator's rights is to be recognised' ${ }^{87}$ Yet the court rulings make no specific mention of the role of creator, instead giving precedence to the most recent and most specific privilege. Lassus' role as an author is mentioned in the context of his selling books himself; while there is no other evidence that he acted as a bookseller, the Hofrat's wording suggests a concern to protect books as items of publishers' stock rather than as intellectual objects.

Indeed in the early seventeenth century, musicians who held printing privileges tended to be those who published their own compositions, including Johann Hermann Schein, Heinrich Schütz and Johannes Schultz. In his 1617 supplication to the Elector of Saxony, Schütz explained that a privilege would protect his investment in publication, specifically against the risk that 'on completion of the opus, experienced booksellers and printers might immediately undertake to publish, reprint and sell it; consequently my copies might remain unsold and cause me significant and considerable harm' ${ }^{88}$ Schein also noted the importance of a privilege in upholding the accuracy of texts: 'many times, carefully disseminated things among others are liable to be reprinted with mistakes, not without special prejudice and disadvantage to the author' (a point previously made by Lassus in his 1581 application for an imperial privilege) ${ }^{89}$ Thus for composers who self-published, a privilege offered protection not merely for their financial investment in an edition, but also for the reputation that might be gained through dissemination of accurate texts. For buyers of printed music, a privilege therefore might signal texts that were more likely to be trustworthy and hence worthy of purchase.

\section{Conclusions}

The mechanism of imperial privileges offered protection from piracy within the empire, but no guarantee outside the emperor's jurisdiction. Books printed within the empire were regularly pirated by the printers of Lyons, Paris and Venice. Privileges issued in territories such as Electoral Brandenburg and Saxony were equally limited in their efficacy, providing 
no protection in the Holy Roman Empire more widely. ${ }^{90}$ Although the existence of a privilege implied a certain cachet, the process of application was tedious and involved some expense, and was no guarantee of success. For many twentieth-century scholars such as Hansjörg Pohlmann, living in an age in which intellectual property is hedged about by legal protections as a matter of course, there may have been a temptation to exaggerate the attractiveness and pervasiveness of privileges. However, the low incidence of titles bearing privileges in the $v d m$ database - less than $5 \%$ - suggests that these legal instruments were relatively unattractive to authors, printers and publishers of music in the decades before 1550. After 1550, as mechanisms for regulating the book trade became more developed with the establishment of the imperial and Saxon book commissions, privileges appear to have been more widely used, particularly for partbook editions issued in the 1570s and 1580 s.

A privilege held a variety of meanings of authors, publishers and consumers. For publishers, the decision of whether to apply for a privilege demanded a calculation balancing projected profits against the expense and bother of acquiring a privilege. It is probably no coincidence that the middle of the sixteenth century, when the imperial chancery began to regulate book privileges more effectively, also saw the publication of the first treatise on insurance, the science of balancing present costs against future risk, Tractatus de assecurationibus et sponsionibus mercatorum, by the jurist Pedro de Santarém, printed at Venice in 1552 - without a privilege. ${ }^{11}$ A privilege could easily be understood as a kind of insurance against potential loss. At the same time, a privilege could be a powerful statement of prestige, enhancing buyers' impressions of the authority and value of editions. Privileges are prominently displayed in some of the most lavish music books of the sixteenth century, such as Adam Berg's Patrocinium musices series containing sacred polyphony by Lassus, where the excerpt from the imperial privilege (see Figure 9.2) complements the display of authority given by the title page (with its depiction of coats of arms of Catholic rulers who support music) and the frontispiece portrait of Crown Prince Wilhelm of Bavaria. ${ }^{92}$ A study of printing privileges therefore highlights the different ways in which music books carried value in the sixteenth century, offering clues as to the commercial and non-commercial motives of authors and publishers.

\section{Appendix 9.1 Draft of privilege granted to Matthias Apiarius, 27 May 1544}

Wir Ferdinand von Gottes genaden Römischer Khünig zu allen Zeitten Merer des Reichs/ In Germanien/ zu Hungern/ Beheim/ \&c Khünig/ Infant in Hispanien/ Ertzhertzog zu Österreich/ Hertzog zu Burgundi/ Steyr/ Kärndten/ Chrain/ vnnd Wirttemberg \&c Graue zu Tÿrol \&c Bekhennen offenlich mit diesem Brieff/ vnd thuen khundt/ allermenigclich/ Als vns vnser/ vnd des Reichs getrewer/ Mathias Apiarius Noricus/ Eingesessner zu Bern in Vchland vnderthenigclich fürbracht/ vnd zuerkhennen geben/ wie das Er allen liebhabern der Khunst [add. supra lineam: zue guet]/ vnd zu khünfftiger gedechtnus/ Etliche Exemplaria/ Compositzen/ vnd Buecher/ Als nemblich von zwaÿerlaÿ Magnificat ad omnes Tonos/ Responsorijs/ Hymnis/vnd Muteten/ Auch so Musicam/ Arithmeticam/ Cathologum Annorum/ vnd Principum/berürt/ [add. in margine: new Gesäng/ Compositzen vnd Muteten new gaystlich vnd weltliche Gesäng/ Compositzen vnd Muteten Auch anders jn Musica vnd Aritmethica (sic)] vnder den Titlen Johannis Vaminj [sic] Brisgoij / Cosme Aldarinj/ Sixti Theoderici/ vnd annderer/ fürnemens were/ in ordenlichem 
druckh ausgheen zelassen/ Vnd aber besorgen müesste/ das jme solche werckh/ von andern/ zu jrem selbst nutz/ vnd vort<ei>l/ vnd jme zuuerderblichen schaden alspaldt nachgedrückht werden möchten. Mit vnderthenigistem anrueffen/ vnd bitten/ das wir jme hierjnn zu furkhombung seines nachtails/ vnd schadens/ mit vnnserer genedigen hilff/ vnd fürsehung genedigclich zuerscheinen geruechten/ Das wir demnach genedigclich angesehen gemelts Mathiasen Apiarij vnderthenig diemuetig bette/ Auch sein gehabte Arbait/ mue/ vnd vleyß/ Vnd derhalben/ Als Römischer Khünig gemeltem Mathiasen Apiarij/ diese besonder genad gethan/ vnd freyhait gegeben/ Thuen auch solches hiemit aus Römischer Khunigclicher macht/ volkhomenhait wissentlich in khrafft ditz briefs / Also das Er obbenente Exemplaria [add. supra lineam: Gesänge]/ Compositiones/ vnd Büecher/ in ordenlichen druckh volenden/ vnd offenlich ausgheen lassen mug. Vnd jme dieselben in sÿben Jaren den negsten beÿ verlierung solcher Büecher/ Vnd nachvolgender Peen/ von niemanden nachgedruckht/ noch also nachgedruckt/ weder haimblich/ noch offenlichen verfuert/ vmbgetragen/ failgelegt/ noch verkhaufft werden sollen/ in khain weiß noch weeg. Vnd gebietten darauff allen/ vnd jeden vnsern/ vnd des Reichs/ Auch vnnserer khünigReiche/ Fürstenthumben/ vnd Lannde vnderthanen/ vnd getreuen/ in was wirden/ stanndt/ oder wesen/ die sein/ Vnd insonderheit allen/ vnd jeden Buechdruckhern/ vnd Buechfuerern Ernstlich/ vnd vestigclich mit diesem Brieff/ vnd wellen. Das sÿ gemelten Mathiasen Apiarium/ beÿ dieser vnser genad/ vnd Freÿhait berueblich beleiben lassen/ Dawider nit dringen/ noch beschweren/ noch des ÿemandt andern zuethuen gestatten in khain weiß/ Als lieb ainem jeden seÿ/ vnser/ vnd des Reichs schwere vngenad/ vnd straff/ Vnd dartzue ain Peen benenntlichen zehen Marckh löttigs goldts zuuermeiden. Die ain jeder so offt Er frauenlich hiewider thätte vns halb in vnser/ vnd des Reichs Chamer/ vnd den andern halben thail obgemeltem Mathiasen Apiario vnablößlich zuebetzalen verfallen sein sol. Das ist vnnser Ernsstliche maÿnung/ Mit vrkhundt ditz Brieffs. Geben in vnnser/ vnd des Reichs Stat Speÿr den sibenvnd zwaintzigisten tag des Monnats Maÿ/ Anno \&c im vierundviertzigisten. Vnnserer Reiche des Römischen im viertzehenden/ vnnd der andern im Achtzehenden.

Ad mandatum domini Regis proprium

H. Renner

Source: Vienna, Haus-, Hof- und Staatsarchiv, RHR, Impressoria 2-23, fol. $168^{v}$.

\section{Appendix 9.2 Supplication of Hans Kilian, approved 26 April 1544}

Allerdurchluchtigister/ Großmecht<igister〉 Kaÿser/ Allergnedigister Herr/ Welhermassen die hochlöblich Kunst/ der Musica/ aus dero all anndere Freÿe Künsten entspringen/ zu gottes Eer/ geschaffen/ vnd von allen hochweisen/ für notwendig zebrauchen gebrisen/ ist Eur Kaÿserlicher Maiestet genedigist bewisst/ vnd derhalb/ von vnnöten zuuerzelen/ Dieweil dann zu gleicherweis/ alle geschöpf/ in zuenennung jrer würgkung/ jren schöpfer Preisen vnd erheben/ Also auch Eur Kaÿserliche Maiestet in austailung jrer Maiestet gnaden/ nit minder/ dann die Freÿen Künst/ durch den brauch vnd vbung/ dero liebhaber/ jmmer ÿe mer/ erhebt werden/ Vnd aber sölhe Kunst der Musica/ gleichwol durch ains tails Instrument/ Tabulatur/ vnd anndere Musicalische bücher/ aber vnuolkommen/ jmm drugkh ausgangen/ bisher/ villeicht aus vnfleis/ oder vntrew/ den Jungen verhallten (wie es dann so Er treulich gemaint/ nit beschehen söllte) zum tail gar vngedrugkht bliben ist/ So hab jch aus mitleidenlicher bewegnus / be ÿ 
ettlichen fürnemen kunstreichen Musicis/ vnd erfarnen Instrumentisten/ souil ver- [fol. 279v ] mugt/ vnd für die Hannd bracht/ dasselb nun/ zuuor Eur Kaÿserliche Maiestet zu Eeren/ vnd allen anfahenden liebhabern/ der löblichen Kunst Musica/ zu gutem/ in drugkh zeferttigen/ vnd ausgeen zelassen/Vnd damit jch aber/ inn bedengkhung des schweren/ vnd grossen cosstens / so wir darauf geen wirdt/ nachdrugkhenshalb/ nit gehindert/ noch in mergklichen meinen schaden vnd verderben kommen mög/ So ist an Eur Kaÿserliche Maiestet/ als mein allergnedigisten Herrn/ mein vnndertenigists bitten/ Eur Kaÿserliche Maiestet/ welle mir/ Ain Priuilegium vnd Freÿhait (on welhe jch nichts ins wergkh bringen kan noch mag) des jnnhallts / das aller mein Musicalischer drugkh/ souil jch/ dess/ auf waserlay Instrument es sey/ Orgl/ oder lautten Tabulatur/ oder gsang/ vnd was jch sonst darzwischen/ von Allerlaÿ schriften/ in den nechstuolgenden zehen Jarn/ ausgeen lassen würd/ Auch ain ÿdes wergkh/ von seinem dato/ vnd ausganng an/ auch in Zehen Jarn/ beÿ ainer Peen/ nit nachgedrugkht werden söll/ allergnedigist mittailen/ vnd sölichs vor [280r] nie gesehens wergkh/ an Eur Maiestet nit erwirden lassen/ Das vmb Eur Kaÿserlicher Maiestet mein lebenlanng/ vnndertenigist zuuerdienen/ erkhenn jch/ mich schuldig vnd willig/

Eur Kaÿserlicher Maiestet Vnndertenigister Diener

Hans Kilian

[Decision on fol. 280v:] Ist bewilligt/ auf Tabulatur Actum in consilio jmperiali 26 Martij $\mathrm{A}^{\circ} 44$

Source: Vienna, Haus-, Hof- und Staatsarchiv, RHR, Impressoria 35-35, fol. 279'-280v

\section{Appendix 9.3 Draft of privilege granted to Paul Köpfel, 30 May 1559}

Allerdurchleuchtigister Großmechtigister vnüberwinndlichster Romischer Kayser allergnedigister Herr Euer Romischen Kaÿserlichen Maiestet seÿenn meine allervnderthonigste ganntz getrewe vnd gehorsame diennst alles hochstenn vermogenns yeder zeit beuor / Alls Euer Romischen Kaÿserlichen Maiestet höchstloblichster vorfare Karl Romischer Kayser \&c weÿlannt Wolffganng Kopflinn gewesenn Bürgern zu Straßburg meÿnem liebenn vatter seligenn zu seinem buchtrucker hanndel mit ainem Kayserlichen priuilegio aller gnedigst begabet vnnd gefreÿett/ vff form vnnd massenn wie bejuerwarte Collacionierte vnnd vnnderschrÿbene abschrifft außweyßt vnnd mit brinngt/ Er meinn vatter aber hie zwischenn mit tod verscheÿden jnn dessen getrÿbenen hanndel jch sein verlassener Sonne eingedrettenn/ Nunn kann aber Eurer Römischen Kayserlichen Maiestet alls einem mittleÿdennlichenn aller gnedigst Haupt jch aller vnderthonigst nit verhaltenn/ das bemelter meÿn vatter seliger nach erlanngung bestimpten Kayserlichen Priuilegij einen mercklichen ansehenlichenn schadenn durch ein Schÿffbruch auff dem Rhein erlÿttenn Welchenn schadenn er biz, jnn sein ennde/ nicht wider erholenn oder ergötzt werdenn mog darann auch jch [fol. 348v] vnnd annders meine geschwistert nach des vatters seligenn absterbenn nach zu buesenn vnnd zu bezalenn haben Demnach so gelangt ann Eure Romische Kaÿserliche Maiestet mein aller vnnderthanigst hochfleissigs flehlichs bittenn die geruchenn sich ditz aller gnedigst erbarmen zelassenn/ Vnnd zu wider ergotzlichait/ das bejverwart allts Kayserliches priuilegium/ auf mich vnd meine erbenn aller gnedigst zu verwennden vnnd die Auff zehenn Jar lanng setzen vnnd bestÿmmen lassenn/ vnnd solche gnaden auß Kayserlichem aller miltistem gemüth mir aller gnedigst nit zu verwaÿgernn/ vnnd also zu sonndern gnaden aller gnedigst zuerscheinen/ das will gegen Eure Romische 
Kayserliche Maiestet jch alle Zeit meins lebenns dannckpar vnnd jnngedennck sein/ Vnnd es daneben jnn aller hochsten vnnderthonigkait alles vermogenns mit darstreckung liebs vnd gutts aller vnnderthonigst verdienenn/ thue mich derenn zu gnadenn aller vnnderthonigst beuelhennde/ dern allergnedigstenn anntwurt erwartennde.

Euer Romischen Kayserlichen Maiestet Aller vnnderthonigster gantz getrewer vnd gehorsamer

Paulus Köpfflin

Buchtrucker vnnd Bürger zu Wormbs

[Decision on fol. 349r:] Fiat ain Renouation diß Priuilegiums wie es sein Vatter gehabt/ Vnnd auf drej Jar lanng Den 30 Maij A $^{\circ}$ \&c $59^{\circ}$

Source: Vienna, Haus-, Hof- und Staatsarchiv, RHR, Impressoria 38-34, fol. 348 ${ }^{\mathrm{r}}-349^{\mathrm{v}}$.

\section{Notes}

1 Summary catalogue in Koppitz, Die kaiserlichen Druckprivilegien.

2 Gieseke, Die geschichtliche Entwicklung, 62-63. On the recent reorientation of the history of copyright law, see Kretschmer, 'The History of Copyright History'. For accounts of analogous structures in different jurisdictions, see Armstrong, Before Copyright; Nuovo, The Book Trade, 195-257.

3 Pohlmann, Urheberrecht, 190.

4 Rose, 'Protected Publications', 249-250, 284.

5 Taylor, 'Vernacular Authorship'.

6 Perlbach, Die Statuten des Deutschen Ordens, 30: 'sô ein iegelich geistlich leben mit prîvilêgien unde vrîheite des stûles von Rôme sî ûzgenomen von werltlichem gerihte'. Cf. Deutsches Rechtswörterbuch [henceforth DRW], 10: 1320-1321.

7 Foltz, Urkundenbuch, 1: 68; DRW 4: 969-970, Gnade (VI).

8 Grimm and Schröder, Weisthümer, 1: 120; DRW 5: 851-852, Herrlichkeit (II 6).

9 DRW 10: 1323-1324, Privileg II.

10 DRW 10: 1324-1325.

11 Rose, Musical Authorship, 118-121.

12 Armstrong, Before Copyright, 1. The distinction between copyright and privilege was already adumbrated in one of the first important copyright cases in England, Tonson v. Collins (1761), in which Edward Thurlow, acting for the defendant, declared that 'the privileges granted imply no idea whatsoever of copy-right in authors. They relate merely to printers, as if in nature of a patent for this new invention of publication'; see Blackstone, Reports of Cases, 1: 308. Although privileges could indeed be granted to authors as well as publishers, Thurlow's distinction between privileges and copyright remains important. Text of Tonson available in Primary Sources on Copyright.

13 'Et quoniam tale inventum, aetatis nostrae peculiare et proprium ... omni fauore et ope augendum atque fovendum est.' Johannes of Speyer's Printing Monopoly, Venice (1469), Primary Sources on Copyright.

14 'siando fama celebratissima vostra serenitá cum sue concession et privilegij invitar, et excitar li inzegni ad excogitar ogni dì nove invention qual habiano esser acommodita, et ornamento publico'. Transcribed in Boorman, Ottaviano Petrucci, 1146; see also ibid., 77-108.

15 Durantaye, 'The Origins'.

16 Love, Scribal Publication.

17 Adam, 'The Profession of Printer', 13-16.

18 McDonald, "'Burned to Dust"'.

19 Missale Vratislaviense (Kraków: [Kaspar Hochfeder]), 1505), vdm 867, fol. [a]1r: 'Iohannes Turzo Decanus \& coadiutor Electus ac Confirmatus Vratislauiensis. Sacerdotibus \& clericis eiusdem diocesis Salutem. Si quis forte inuidorum malignitate calumpniare velit: hunc missalium librum: velut librariorum vitio mendosum \& deprauatum Hortamur \& monemus omnes ac singulos Vratislaviensis diocesis clericos et sacerdotes ne deterreantur aut se retrahant ab emptione eorundem. Adhibitis enim pluribus atque diuersis exemplaribus: ritus \& ordo Vratislauiensis ecclesie adamussim seruatus est. castigatus itaque et absque omni reprehensione liber hijs tipijs [sic] Cracouiensibus excusus: diligentissimorum Bibliopolarum cura \& elucubratione exiuit In 
communem cleri \& Vratislauiensis diocesis deuotionem ac vtilitatem Valete et religionem colite Vratislauie die Mercurij prima Iulij. M.ccccc.v'.

20 See Duggan, 'Early Music Printing'.

21 Our account of the form and history of printing privileges is indebted to Lehne, 'Zur Rechtsgeschichte'. For more recent syntheses, see Koppitz, 'Die Privilegia'; Maclean, Scholarship, 134-151.

22 Lehne, 'Zur Rechtsgeschichte', 390.

23 Rose, 'Protected Publications', 273.

24 Lehne, 'Zur Rechtsgeschichte', 345-347.

25 Ibid., 349.

26 Ibid., 360-361.

27 Eisenhardt, Die kaiserliche Aufsicht, 64-66.

28 Gieseke, Die geschichtliche Entwicklung, 29-31.

29 Lehne, 'Zur Rechtsgeschichte', 386.

30 See the chapter by Gustavson in the present book.

31 Lehne, 'Zur Rechtsgeschichte', 341.

32 Maclean, Scholarship, 140.

33 Rose, 'Protected Publications', 251, 253, 257; Haar, 'Orlando di Lasso', 135, 140-142.

34 Koppitz, 'Die Privilegia', 195.

35 Schottenloher, 'Die Bücherprivilegien', 91.

36 Maclean, Scholarship, 138.

37 Lehne, 'Zur Rechtsgeschichte', 361.

38 Rose, 'Protected Publications', 271.

39 Lehne, 'Zur Rechtsgeschichte', 389.

40 Vienna, HHStA, Reichsregisterbuch Karl V 22, 36v, cit. Lehne, 'Zur Rechtsgeschichte', 389 n 206.

41 Rose, 'Protected Publications', 277.

42 'Hac tamen speciali quoque lege adiecta: ut cantiones hae tam in praefationibus, quam in contextu nihil quicqua $\triangleleft \mathrm{m}>$ scandalosum, aut adversum orthodoxae religioni Catholicae, vel etia $<\mathrm{m}>$ Imperii constitutionibus in se contineant.' HHStA, RHR, Impressoria, 21-32, fol. 232' . See also Rose, 'Protected Publications', 276.

43 Lehne, 'Zur Rechtsgeschichte', 377-378.

44 Rose, 'Protected Publications', 274.

45 Arnold Schlick, Spiegel der Orgelmacher (Speyer: Peter Drach III, 1511), fol. A2 $2^{\mathrm{r}}-3^{\mathrm{r}}$. This book does not appear in the $v d m$ database because it does not contain printed notation.

46 Arnold Schlick, Tabulaturen etlicher Lobgesang und Lidlein uff die Orgeln und Lauten (Mainz: Peter Schöffer the Younger, 1512), vdm 12, fol. A1 .

47 Ottmar Luscinius, Musurgia seu praxis musicae (Strasbourg: Johann Schott, 1536), vdm 215, 2nd ed. Strasbourg: Johann Schott, 1542, vdm 1329.

48 Liber selectarum cantionum quas vulgo mutetas appellant (Augsburg: Sigmund Grimm and Marx Wyrsung, 1520), vdm 18.

49 Cantiones quinque vocum selectissimae (Strasbourg: Peter Schöffer the Younger, 1539), vdm 44.

50 Vienna, HHStA, RHR Impressoria 56-41.

51 Gustavson, 'Hans Ott', 130-132, 158-165. As Gustavson points out, it is unclear who held the unusually long six-year privilege to the following two editions, though it is possible that Ott was involved as distributor: Wilhelm Breitengraser (ed.), Trium vocum carmina (Nuremberg: Hieronymus Formschneider, 1538), vdm 41; Ludwig Senfl, Magnificat octo tonorum (Nuremberg: Hieronymus Formschneider, 1537), vdm 98.

52 Novum et insigne opus musicum (Nuremberg: Hieronymus Formschneider, 1537), vdm 35, Tenor partbook, fol. A2 ${ }^{\mathrm{r}-\mathrm{v}}$; German text from Hundert und ainundzweintzig newe Lieder (Nuremberg: Hieronymus Formschneider, 1534), vdm 20, ed. in Geering and Altwegg, Lieder aus Hans Otts Liederbuch von 1534, XV; English translation of the Latin text in Gustavson, 'Hans Ott', 559-560.

53 Hoven, Dictionary of Renaissance Latin, 61, gives 'copyist' as the only meaning for bibliographus.

54 Johannes Frosch, Dic io pean, sacer ordo vatum (Augsburg: Melchior Kriegstein, [c. 1537-1546]), vdm 65; Selectissimae necnon familiarissimae cantiones (Augsburg: Melchior Kriegstein, 1540), vdm 51; Cantiones septem, sex et quinque vocum (Augsburg: Melchior Kriegstein, 1545), vdm 1034; Concentus octo, sex, quinque et quatuor vocum (Augsburg: Philipp Ulhart the Elder, 1545), vdm 1033; Gradatio sive scala (Augsburg: Philipp Ulhart the Elder, [c. 1545]), vdm 1183; Cantiones septem, 
sex et quinque vocum (Augsburg: Melchior Kriegstein, 1546), vdm 1064; Cantiones selectissimae (Augsburg: Philipp Ulhart the Elder, 1548), vdm 1119; Ulrich Brätel, Ecce quam bonum (Augsburg: Philipp Ulhart the Elder, 1548), vdm 1182; [Three canonic motets] (Augsburg: [Philipp Ulhart the Elder], [1548]), vdm 1180; Cantiones selectissimae liber secundus (Augsburg: Philipp Ulhart the Elder, 1549), vdm 1121.

55 The text is given in Selectissimae necnon familiarissimae cantiones (Augsburg: Melchior Kriegstein, 1540), vdm 51, Tenor partbook, fol. [ $\alpha] 2^{\mathrm{r}}$, reprinted (with some errors) by Pohlmann, Urheberrecht, 265.

56 See the chapter by Van der Miesen in this book for an example of the harm that a printing monopoly could cause.

57 On secrecy among instrumentalists, see Rose, 'Musical Authorship', 121-123.

58 Gustavson, 'Hans Ott', 1: 131.

59 Hans Neusidler, Ein newgeordent künstlich Lautenbuch (Nuremberg: Johann Petreius, 1536), vdm 33 , fol. $a 2^{\mathrm{r}}$.

60 Hans Neusidler, Ein newes Lautenbüchlein (Nuremberg: Hans Guldenmund, 1540), vdm 54.

61 Buchwald, 'Stadtschreiber M. Stephan Roth', 175.

62 Johannes Wannenmacher, Bicinia sive duo, germanica ad aequales. Tütsche Psalmen vnnd andre Lieder (Bern: Matthias Apiarius, 1553), VD16 ZV 8930, RISM A/I W 202, RISM B/I 1553¹, fol. $A 3^{r}$ : 'So ich denn spür solche ringe vnnd kleine gab/ by eüch vnnd anderen ettwas angnem syn/ will ich in kurtzem grössers vnd bessers harnach kommen lassen/ dann es ist nit ein kleiner schatz/ der edlen Musica/ durch gedachten Joannem Vannium/ Cosmam Alderinum/ vnd Sixtum Theodericum/ alle seliger gedechtnuß/ verlassen [...]' ('Since I perceive that such gifts, albeit modest and small, are somewhat pleasant to you and others, I wish in the near future to release something larger and better, for it is no small treasure of the noble art of music, left behind by the aforementioned Johannes Wannenmacher, Cosmas Alder and Sixt Dietrich, all deceased $\left.[\ldots]^{\prime}\right)$.

63 Cosmas Alder, Hymni sacri numero LVII. quorum usus in Ecclesia esse consueuit, iam recens castigati: $\mathcal{E}$ eleganti planè modulatione concinnati (Bern: Matthias Apiarius; Basel: Michael Isengrin, 1553), VD16 A 1699; RISM A/I A 812.

64 Kmetz, '250 Years of German Music Printing'; Giselbrecht, 'Melchior Lotter'.

65 See the privileges for Marcus Bollius, Johann Groppengiesser, Johann Knöfel, Johann Christoph Roberti, Wilhelm Hieronymus Stenger and Adolph Weissenhan, detailed in Rose, 'Protected Publications', 252-255, 259, 262.

66 Psalmen, Gebett und Kirchenübung wie sie zu Straßburg gehalten werden (Strasbourg: Wolfgang Köpfel, 1526), vdm 308, fol. A1 v: ‘Wolff Köpphel zu dem leser. Nach dem ich Keyserlich freyheyt hab/ das man mir nichts soll nach trucken/ vnd aber dises kirchen gesang von mir erstlich getruckt ist/ wil ich mänglich verwarnet haben/ das niemandts sollichs nachtrucken oder anderßwo gedruckt verkauffen wölle/ sonst würde ich getrungen nach Keyserlicher freyheyt wider solliche so vil möglich zehan deln/ wiewol das büchlin klein ist/dann dar an gelegen seyn will/ das nur auffs fleyssigst was das wort Gotts belangt außgehe/ vnd soll auch niemandt wider Keyserliche gepott eim andern schaden zů fiegen/ das sonst von Gott vnnd der natur verbotten ist'.

67 Christopf Ruedolff, Behend vnnd Hubsch Rechnung durch die kunstreichen regeln Algebre/ so gemeincklich die Coss genennt werden (Strasbourg: Wolfgang Köpfel, 1525), VD16 R 3435, fol. A1 ${ }^{\text {r: }}$ 'Mit Keiserlichen Freiheiten diß bůch in dreien jaren nit nach zů drucken/ bey peen zehen marck golds vnd verlierung der bücher'. Wolfgang Capito, Hebraicarum institutionum libri duo (Strasbourg: Wolfgang Köpfel, 1 April 1525), VD16 C 824, fol. A1': 'Cum privilegio Imperiali, ad Triennium'.

68 Psalmen, Gebett und Kirchenübung wie sie zu Straßburg gehalten werden (Strasbourg: Wolfgang Köpfel, 1530), vdm 375. This edition contains the same warning against piracy as the 1526 editions.

69 See, for example, [Markgraf Georg von Brandenburg], Von dem Gebrauch der heiligen hochwirdigen Sacramenten ([Berlin]: [Hans Weiss], 1540), vdm: 871; 2nd ed. 1542, vdm: 1197.

70 RISM A/I D 3520, 3524.

71 For example, Nikolaus Selnecker, Christliche Psalmen, Lieder und Kirchengesenge (Leipzig: Johann Beyer, 1587), VD16 S 5494.

72 Rose, 'Protected Publications', 258, 260.

73 The existence of an Electoral Brandenburg privilege is stated on the title page of Bartholomaeus Gesius, Psalmodia choralis (Frankfurt an der Oder: Friedrich Hartmann, 1600), RISM A/I G 1689, and may have been the unspecified privilege that is indicated with the 'Cum Gratia et Privilegio' 
rubric on other items in Gesius' output, such as Geistliche Deutsche Lieder (Frankfurt an der Oder: Johann Hartmann, 1601), RISM A/I G 1690.

74 For a statistical demonstration of the increasing importance of single-composer editions, see Rose, 'Writing a Big Data History of Music', 651-652.

75 Orlande de Lassus, Patrocinium musices (Munich: Adam Berg, 1573), RISM A/I L 857, privilege printed on final page.

76 For examples, see Johann Knöfel, Dulcissimae quaedam cantiones (Nuremberg: Theodor Gerlach, 1571), RISM A/I K 989; Jakob Meiland, Selectae cantiones quinque et sex vocum (Nuremberg: Dietrich Gerlach, 1572), RISM A/I M 2178; Leonhard Lechner, Sacrarum cantionum quinque et sex vocum. Liber secundus (Nuremberg: Katharina Gerlach and heirs of Johann Berg, 1581), RISM A/I L 1295).

77 RISM B/I 1603ㅜㄹ RISM A/I B 3241; RISM A/I B 3242. Dresden, Sächsisches Hauptstaatsarchiv, Loc. $10757 / 1$, fol. $313^{v}$.

78 Rose, 'Protected Publications', 252-253. Privileges ed. in Pohlmann, Urheberrecht, 267 (Neusidler), 270 (Bakfark).

79 Elias Nikolaus Ammerbach, Ein new kunstlich Tabulaturbuch (Leipzig: Johann Beyer, and Nuremberg: Dietrich Gerlach, 1575), RISM B/1 $1575^{17}$.

80 Rose, 'Protected Publications', 253. Privilege ed. in Pohlmann, Urheberrecht, 270-271.

81 Rose, 'Protected Publications', 252-254. Privileges ed. in Pohlmann, Urheberrecht, 272-273 (Handl), 273-274 (Hassler), 274-276 (Sales).

82 Gallus Dressler, Opus sacrarum cantionum, 2nd ed. (Nuremberg: Katharina Gerlach, heirs of Johann Berg, and Wolfgang Kirchner, 1577), RISM A/I D 3522.

83 Ibid.

84 Orlande de Lassus, Fasciculi aliquot sacrarum cantionum cum quatuor, quinque, sex et octo vocibus (Nuremberg: Katharina Gerlach, 1582), RISM L 937.

85 'dieweil sie die gesang mit wissen und gutem willen deß Orlandi gedruckt und derselbig sich auf ein anderes und besseres specialprivilegium züge'. Cited in Pohlmann, Urheberrecht, 166.

86 'Weil das Privilegium generale vnd nit in specie auff diese gesang außgangen, Item a Max. 2 vnd also per mortem eius expiriet. Item man nit weis ob der zu Nurnberg ein besonder privilegium hatt oder nit, sonderlich weil der author selbst ime die Bücher verkaufft hatt, Item die Executio im privilegio stehet, daß der die Bücher selbst möge nemen, so hatt dis begeren nit statt'. HHStA, RHR Resolutionsprotokolle saec. XVI 47, fol. 28 ${ }^{\text {r }}$. Cited in Pohlmann, Urheberrecht, 166.

87 'das beachtliche Gefühl für eine begriffliche Trennung des "Verleger-Rechts" vom "UrheberRecht" zu erkennen ....' Pohlmann, Urheberrecht, 167.

88 'nach verfertigung des operis, geübte buchhändtler vndt drucker vntterstehen, daßelbe also baldt aufzulegen, aufs newe widrumb nachzudrucken, vndt ferner zuvorhandlen, dannenhero mir dann meine exemplaria, ersitzen bleiben, vndt mercklicher großer schade, zugefügt werden möchtte'. D-Dla, Loc. 10757 / 2 [volume wrongly numbered 10757/3], fol. 85' . See also Rose, 'Protected Publications', 281.

89 'vielmahl wolabgesande sachen von andern, nicht ohne sonderliches praejudi<cium` vndt nachtheil der authorn vitiose nachgetrucket zuwerd «e`n pflegen ....' D-Dla, Loc. 10757/2 [volume wrongly numbered 10757/3], fols. 60 $-61^{\mathrm{r}}$; transcribed and translated in Rose, 'Protected Publications', 304-306. On Lassus, see Rose, 'Protected Publications', 280.

90 Rose, 'Protected Publications', 291-292.

91 Koch, Pioniere, 17-18; more generally on financial calculations of risk aversion, see Cevolini, 'Der Preis der Hoffnung'.

92 Orlande de Lassus, Patrocinium musices (Munich: Adam Berg, 1573). RISM A/I L 857.

\section{References}

Adam, Renaud. 'The Profession of Printer in the Southern Netherlands before the Reformation. Considerations on Professional, Religious and State Legislations'. In Church, Censorship and Reform in the Early Modern Habsburg Netherlands, edited by Violet Soen, Dries Vanysacker and Wim François. Bibliothèque de la Revue d'histoire ecclésiastique 101. Turnhout: Brepols, 2017, 13-25.

Armstrong, Elizabeth. Before Copyright: The French Book-Privilege System 1498-1526. Cambridge: Cambridge University Press, 1990. 
Blackstone, William. Reports of Cases Determined in the Several Courts of Westminster-Hall, from 1746 to 1779, edited by Charels Heneage Elsley. 2 vols. London: Sweet, Pheney, Maxwell, Stevens \& Sons, 1828.

Boorman, Stanley. Ottaviano Petrucci: Catalogue Raisonné. Oxford and New York: Oxford University Press, 2006.

Buchwald, Georg. 'Stadtschreiber M. Stephan Roth in Zwickau in seiner literarisch-buchhändlerischen Bedeutung für die Reformationszeit'. Archiv für Geschichte des Deutschen Buchhandels 16 (1893): 6-246.

Cevolini, Alberto. 'Der Preis der Hoffnung'. In Die Ordnung des Kontingenten: Beiträge zur zahlenmäßigen Selbstbeschreibung der modernen Gesellschaft, edited by Alberto Cevolini. Wiesbaden: Springer, 2014, 177-207.

Deutsches Rechtswörterbuch. Weimar: Böhlau, 1914-.

Duggan, Mary K. 'Early Music Printing and Ecclesiastic Patronage'. In Early Music Printing in German-Speaking Lands, edited by Andrea Lindmayr-Brandl, Elisabeth Giselbrecht and Grantley McDonald. London and New York: Routledge, 2018, 21-45.

Durantaye, Katharina de la. 'The Origins of the Protection of Literary Authorship in Ancient Rome'. Boston University International Law Journal 25 (2007): 37-111.

Eisenhardt, Ulrich. Die kaiserliche Aufsicht über Buchdruck, Buchhandel und Presse im Heiligen Römischen Reich Deutscher Nation (1496-1806). Karlsruhe: C. F. Müller, 1970.

Foltz, Max, ed. Urkundenbuch der Stadt Friedberg. 2 vols. Marburg: Elwert, 1904-1987.

Geering, Arnold and Wilhelm Altwegg, eds. Lieder aus Hans Otts Liederbuch von 1534. Das Erbe Deutscher Musik 15. Wolfenbüttel and Berlin: Kallmeyer, 1940.

Gieseke, Ludwig. Die geschichtliche Entwicklung des deutschen Urheberrechts. Göttingen: Otto Schwartz, 1957.

Giselbrecht, Elisabeth. 'Melchior Lotter, a German "Music Printer"'. In Early Music Printing in German-Speaking Lands, edited by Andrea Lindmayr-Brandl, Elisabeth Giselbrecht and Grantley McDonald. London and New York: Routledge, 2018, 123-134.

Grimm, Jacob (ed., vols. 1-4) and Richard Schröder (ed., vols. 5-7). Weisthümer. Göttingen: Dieterich, $1840-1878$.

Gustavson, Royston. 'Hans Ott, Hieronymus Formschneider, and the Novum et insigne opus musicum (Nuremberg, 1537-1538)'. PhD dissertation, University of Melbourne, 1998.

Haar, James. 'Orlando di Lasso, Composer and Print Entrepreneur'. In Music and the Cultures of Print, edited by Kate van Orden. New York: Garland, 2000, 125-162.

Hoven, René. Dictionary of Renaissance Latin from Prose Sources. 2nd edition. Leiden: Brill, 2006.

Kmetz, John. '250 Years of German Music Printing (c. 1500-1750): A Case for a Closed Market'. In NiveauNischeNimbus: Die Anfünge des Musikdrucks nördlich der Alpen, edited by Birgit Lodes. Wiener Forum für ältere Musikgeschichte 3. Tutzing: Hans Schneider, 2010, 167-184.

Koch, Peter. Pioniere des Versicherungsgedankens. Wiesbaden: Springer, 1968.

Koppitz, Hans-Joachim. Die kaiserlichen Druckprivilegien im Haus-, Hof- und Staatsarchiv Wien: Verzeichnis der Akten vom Anfang des 16. Jahrhunderts bis zum Ende des Deutschen Reichs (1806). Wiesbaden: Harrassowitz, 2008.

Koppitz, Hans-Joachim. 'Die Privilegia impressoria des Haus-, Hof- und Staatsarchivs in Wien'. Gutenberg-Jahrbuch 69 (1994): 187-207.

Kretschmer, Martin, Lionel Bently, and Ronan Deazley. 'Introduction. The History of Copyright History: Notes from an Emerging Discipline'. In Privilege and Property: Essays on the History of 
Copyright, edited by Ronan Deazley, Martin Kretschmer, and Lionel Bently. Cambridge: Open Book, 2010, 1-20.

Lehne, Friedrich. 'Zur Rechtsgeschichte der kaiserlichen Druckprivilegien. Ihre Bedeutung für die Geschichte des Urheberrechtes'. Mitteilungen des Österreichischen Instituts für Geschichtsforschung 53 (1939): 323-409.

Love, Harold. Scribal Publication in Seventeenth-Century England. Oxford: Clarendon Press, 1993.

Maclean, Ian. Scholarship, Commerce, Religion. The Learned Book in the Age of Confessions, 1560-1630. Cambridge, MA: Harvard University Press, 2012.

McDonald, Grantley. "“Burned to Dust": Censorship and Repression of Theological Literature in the Habsburg Netherlands During the 1520s'. In Church, Censorship and Reform in the Early Modern Habsburg Netherlands, edited by Violet Soen, Dries Vanysacker and Wim François. Bibliothèque de la Revue d'histoire ecclésiastique 101. Turnhout: Brepols, 2017, 27-52.

Nuovo, Angela. The Book Trade in the Italian Renaissance, translated by Lydia G. Cochrane. Leiden: Brill, 2013.

Perlbach, Max, ed. Die Statuten des Deutschen Ordens nach den ältesten Handschriften. Halle an der Saale: Max Niemeyer, 1890.

Pohlmann, Hansjörg. Die Frühgeschichte des musikalischen Urheberrechts (ca. 1400-1800). Kassel: Bärenreiter, 1962.

Primary Sources on Copyright (1450-1900), edited by Lionel Bently \& Martin Kretschmer, www.copyrighthistory.org.

Rose, Stephen. Musical Authorship from Schütz to Bach. Cambridge: Cambridge University Press, 2019.

Rose, Stephen. 'Protected Publications: The Imperial and Saxon Privileges for Printed Music, 15501700'. Early Music History 37 (2018): 247-313.

Rose, Stephen, Sandra Tuppen, and Loukia Drosopoulou. 'Writing a Big Data History of Music'. Early Music 43 (2015): 649-660.

Schottenloher, Karl. ‘Die Druckprivilegien des 16. Jahrhunderts'. Gutenberg-Jahrbuch 8 (1933): 89-110.

Taylor, Andrew. 'Vernacular Authorship and the Control of Manuscript Production'. In The Medieval Manuscript Book: Cultural Approaches, edited by Michael Johnston and Michael van Dussen. Cambridge: Cambridge University Press, 2015, 199-214. 